\title{
VAKBEKWAAMHEID EN OPLEIDING VAN DE ORGANISATIE-ADVISEUR
}

\author{
door Prof. Ir. H. Bosch
}

Het is niet alleen een eer maar ook een uitdaging dit netelige onderwerp op verzoek van de redactie te mogen behandelen. Hoewel ik dankbaar gebruik heb gemaakt van suggesties van een aantal - in de voetnoot genoemde - bevriende collega's', blijf ik uiteraard persoonlijk volledig verantwoordelijk voor de inhoud van dit artikel.

Voor de kwaliteit van „organisatie-processen” - het thema van dit bijzondere nummer - speelt de vakbekwaamheid van de adviseur een grote rol, terwijl opleiding in één of andere vorm naast ervaring onontbeerlijk is om voldoende vak. bekwaam te worden en te blijven.

Elders in dit nummer is aandacht geschonken aan het onderwerp ,organisatie adviseur en opleiding”. In dat artikel gaat het vooral over de opleiding door de organisatie-adviseur aan personeel van cliënten-organisaties en eigen bureaus. In dit artikel staat de opleiding van de organisatie-adviseur centraal. Hierbij zullen wij ons beperken tot de formele opleidingsmogelijkheden in Nederland. Voor le. zers, die belangstelling hebben voor bedrijfskundige, c.q. management opleiding in het algemeen wordt verwezen naar de rapporten daterend uit 1971 en 1976 onder redactie van Braun ${ }^{1}$ ), respectievelijk Wattel ${ }^{2}$ ). Het spreekt vanzelf dat een aantal van de daar genoemde opleidingen ook van nut zijn voor de (toekomstige) organisatie-adviseur en dus ook in dit artikel ter sprake komen.

In de aanhef heb ik het onderwerp ,netelig" genoemd. Er zijn tenminste drie aspecten te noemen, die aanleiding kunnen geven tot verschil van mening.

Vragen zijn bijvoorbeeld:

1 Bestaat er een vak organisatiekunde en zo ja, wie bepaalt wat daar wel en daar niet toe gerekend moet worden; wat is dus de breedte van het vak?

2 Wie bepaalt wanneer iemand wel of niet bekwaam is? Welke maatstaven worden dan aangelegd; wat is dus de diepte van het vak?

3 Wie beoordeelt en op grond waarvan of één of andere opleiding voldoende breed en diep is als basis voor het functioneren van een organisatie-adviseur?

Naarmate een grotere groep toonaangevende personen in een samenleving meent op deze vragen eenduidige antwoorden te kunnen geven, is er meer sprake van een erkend vak. Het legitimiteitsvraagstuk zal steeds blijven bestaan.

Een van de doeleinden van de Orde van Organisatiekundigen en -Adviseurs $(\mathrm{OOA})$ is, te bevorderen dat het vak zich verder ontwikkelt en in grote mate erkenning krijgt in de samenleving. Door de grote verscheidenheid aan werkzaamheden die door organisatie-adviseurs worden uitgevoerd is het moeilijk aan te geven, wat tot de essentie van het vak gerekend moet worden. De professionalisering van het beroep van organisatie-adviseur is nog niet zover voortgeschreden

" Mijn dank gaat in het bijzonder uit naar de leden van de commissie toetsing opleidingen van de O.O.A., te weten In 't Veld, Sj. Muller en Verschoor, en naar Braun, Van Dongen en Van Gils. 
als bij artsen, advocaten en accountants het geval is. De verhoging van vakbekwaamheid van de organisatie-adviseur en het bevorderen van goede opleidingsmogelijkheden daartoe, vormt één van de voorwaarden voor verdere professionalisering.

In 1958 werd de Stichting Interacademiale Opleiding Organisatiekunde (SIOO) door economische faculteiten en technische hogescholen opgericht. Het is niet te verwonderen dat de O.O.A. vanaf de oprichting een rol speelt bij het wel en wee van die opleiding.

\section{Organisatie-kunde of organisatie-advieskunde?}

In $1973 \mathrm{kwam}$ de fusie tot stand tussen de Orde van Organisatie adviseurs en het Genootschap van Organisatiekundigen. De leden van het Genootschap waren reünisten van het SIOO. Vóór de fusie telde de Orde ca. 250 leden. Bij de fusie in 1973 traden ca. 150 leden van het Genootschap toe tot de nieuwe Orde van Organisatiekundigen en -Adviseurs (de OOA). Thans telt de OOA ruim 600 leden, waarvan ca. $40 \%$ extern en ca. $40 \%$ intern adviseur zijn, terwijl de overige $20 \%$ voor een belangrijk deel bestaat uit leden die werkzaam zijn in universiteiten of hogescholen. Van de interne adviseurs is ca. $60 \%$ verbonden aan een bedrijf en is de resterende $40 \%$ in dienst van de overheid of andere non profit organisaties.

Het aantal leden van de Orde dat wel organisatiekundige maar geen adviseur is, is dus gering. Bij de bespreking van vakbekwaamheid en opleidingen van de organisatie-adviseur moet dus vooral „organisatie-advieskunde” in de beschouwing betrokken worden.

Alvorens dieper in te gaan op de betekenis van dat begrip, zal ik een poging wagen een aantal andere begrippen, die vaak door elkaar gebruikt worden, in vereenvoudigde termen van elkaar te onderscheiden. Hierbij moet worden be dacht, dat er bij het professioneel uitoefenen van een beroep steeds sprake is van het zo wetenschappelijk en maatschappelijk verantwoord mogelijk handelen, gebaseerd op kennis, inzicht en vaardigheid die verkregen kunnen worden door op. leiding en ervaring.

\section{Onderscheiding van een aantal „-kunden"}

Persoonlijk maak ik de volgende onderscheidingen:

Bij organisatiekunde ligt de nadruk op de analyse van de structuur en van het functioneren van organisaties.

Bij bedrifskunde (in engere zin) ligt de nadruk op de analyse van en het handelen in voornamelijk op grond van winst getoetste organisaties (bedrijven).

Bij bestuurskunde ligt de nadruk op de analyse van en het handelen bij de over. heid en in niet-op-winst-gerichte organisaties.

Bij beleidskunde ligt de nadruk op de analyse, het ontwerpen en het bijstellen van het beleid. Meestal wordt de term gehanteerd voor het beleid van overheids. instanties, terwijl men voor bedrijven spreekt van strategie.

In het bovenstaande is getracht het onderscheid tussen de diverse begrippen te benadrukken. Het is duidelijk dat deze begrippen elkaar voor een deel overlap. pen. De term „,bedrijfskunde” wordt bijvoorbeeld ook als verzamelbegrip gebruikt 
voor alle bovengenoemde „kunden”. Zo bestaat aan de Interfaculteit Bedrijfskun. de te Delft een bestuurskundige variant, waarbij bestuurskunde opgevat wordt als verbijzondering van bedrijfskunde naar het toepassingsgebied.

Aan de TH te Twente daartegenover opende de onderafdeling der Bestuurs. kunde, min of meer gescheiden van de bestaande Afdeling der Bedrijfskunde, in het studiejaar 1976-1977 haar poorten. Met die opleiding bestuurskunde „wordt een bijdrage beoogd aan de opleiding en vorming van hen die in adviserende of leidinggevende functies meewerken in het proces van voorbereiding, vaststelling, uitvoering en evaluatie van overheidsbeleid". In mijn terminologie zou die studie dus eerder met de term beleidskunde aangeduid moeten worden.

\section{Organisatie-advieskunde}

De organisatie-adviseur zal naast de analyse van de structuur en het functioneren van organisaties (organisatiekunde), inclusief de strategie of het beleid (beleidskun. de), in staat moeten zijn op het verzoek van een opdrachtgever een probleem in een cliënten-organisatie door middel van advisering nader tot een oplossing te brengen (advieskunde). Veelal zal met de advisering beoogd worden een veran. dering in de betreffende organisatie te bewerkstelligen (veranderkunde). Een onderscheid met de bedrijfskundige c.q. bestuurskundige in engere zin bestaat erin dat bij hen als "managers" in respectievelijk bedrijf c.q. een overheidsorganisatie het handelen voorop staat, terwijl de organisatie-adviseur zich tot het adviseren beperkt en daardoor minder direct in de organisatie ingrijpt.

Tot voor kort werd een organisatie-adviseur beschouwd als een ,management consultant" in de betekenis van de adviseur van de manager in het bedrijf - of later ook - als adviseur van de "manager” bij de overheid. Thans richt het advies voor de verandering zich niet meer uitsluitend tot de manager maar ook rechtstreeks tot de gehele organisatie, zoals bijvoorbeeld bij organisatie-ontwikkeling het geval is.

Sommige adviseurs rekenen het tijdelijk voorzien in management ook tot hun taak. In dat geval treden zij echter niet op als adviseur maar als bedrijfs. c.q. bestuurskundige in engere zin.

Voor de duidelijkheid is de Engelse vertaling van de Interfaculteit Bedrijfskun. de te Groningen opmerkelijk. De officiële vertaling luidt „School of management and organization".

\section{Kern van het vak, dat door de organisatie-adviseur beoefend wordt}

De kern vormt de organisatiekunde met als verbijzondering de advisering aan (leden van) een cliënten-organisatie om een verandering tot stand te brengen, die tot beter functioneren kan leiden en inhoudelijk en procesmatig zo wetenschappelijk en maatschappelijk verantwoord mogelijk is.

In navolging van $\mathrm{Vis}^{3}$ ) kunnen we stellen dat de organisatie-adviseur zijn functie uitoefent bij adviesprocessen, die plaats vinden in het kader van adviesrelaties. Onder adviesrelaties verstaan wij hierbij relaties

- van vrijwillige aard

- met een tijdelijk karakter

- tussen een professioneel adviseurssysteem en een cliëntsysteem 
- waarin de adviseur een aanwezig of potentieel probleem helpt oplossen en

- waarbij de adviseur geheel of tot op zekere hoogte een outsider is en zodoende afstand kan nemen van de problematiek.

De grote verscheidenheid maakt dat het niet mogelijk is dat een adviseur deskundig is op de inhoudelijke kant van elk organisatorisch probleem. Wel zal hij het vermogen moeten hebben zich snel in te werken op een grote verscheidenheid van problemen. Ook is het niet te verwachten dat een adviseur in staat is elk probleem procesmatig op de optimale wijze te benaderen. Welke benadering optimaal is, hangt namelijk nauw samen met de aard en inhoud van het probleem, terwijl vrijwel in elk advies proces meerdere benaderingen toegepast moeten worden. De grote breedte en verscheidenheid van het vak komt duidelijk naar voren indien men in ogenschouw neemt welke rollen een adviseur kan spelen. Ideaal typisch onderscheiden Blake en Mouton ${ }^{4}$ ) de volgende rollen:

1 Aanvaardend - De cliënt een gevoel van vertrouwen gevend, waarin de cliënt zich vrij voelt om persoonlijke gedachten uit te spreken zonder bang behoe. ven te zijn voor afwijzing of verkeerde beoordeling.

2 Stimulerend . Om de cliënt te helpen gegevens te verzamelen en de perceptie van de gang van zaken daardoor te helpen herzien. De cliënt wordt zich beter bewust van de problemen en kan deze beter aan.

3 Confronterend - De cliënt wordt uitgedaagd na te gaan in hoeverre het waar. de geladen denken, de manier, waarop situaties bekeken worden, kleurt en verstoort. De cliënt ziet daardoor mogelijke alternatieven, die tot meer effectief handelen kunnen leiden.

4 Voorschrijvend - De adviseur vertelt wat de cliënt moet doen om een situatie te verbeteren of doet dat voor hem. De adviseur doet een aanbeveling, die opgevolgd wordt.

5 Theoretisch - Door theorieën aan te bieden, die betrekking hebben op de situatie van de cliënt, helpt de adviseur de cliënt aan systematische en empirisch getoetste kennis. Met behulp van deze theorieën is de cliënt in staat zijn situatie meer analytisch en als een oorzaak-en-gevolg relatie te bezien.

Voor andere onderscheidingen naar diverse rollen wordt verwezen naar artikelen van De Ruyter en Wiersema ${ }^{5}$ ), Van de Vliert ${ }^{6}$ ) en Lippitt en Lippitt ${ }^{7}$ ). Het nut van deze artikelen is, dat de organisatie adviseur zich bewust kan worden van het ,meta probleem”, dat bestaat uit het op meta-niveau kiezen van welke rol op een gegeven moment in een advies proces adequaat is. Reeds Reddin ${ }^{8}$ ) wees in zijn 3-D-theorie op de noodzaak van het verhogen van de stijl-flexibiliteit van personen om verschillende rollen te kunnen kiezen en daadwerkelijk te spelen in verschillende (bedrijfs-)situaties. Naast de grote verscheidenheid in aard en inhoud van problemen en in adequate rollen, zijn er ook nog grote verschillen in gewenste aanpak in methodologische zin. Het aantal methoden en technieken is zeer groot, zoals Kluwer's handboek "management-methoden en -technieken ${ }^{9}$ ) toont. Het is niet te verlangen dat een adviseur deze allemaal kent en daarin voldoende ervaring heeft om zich op dat gebied deskundig te noemen. Dit betekent dat de verzuchting, die uit de titel van het boekje „Organisatie-adviseurs ... ook maar mensen"10) doorklinkt maar al te waar is.

Het totale veld dat door organisatie-adviseurs bestreken wordt, is zo groot, dat men niet (meer) kan spreken van "de vakbekwaamheid en opleiding van de or. 
ganisatie-adviseur". Het gaat blijkbaar om vakbekwaamheid en opleiding van diverse typen organisatie adviseurs. Het idee van een horizontale beroepsorganisatie op basis van "gelijke monniken, gelijke kappen", zal verlaten moeten worden. Veeleer zal erkend moeten worden dat er teveel schakeringen voorkomen in de breedte en de diepte van het vak om naar homogeniteit te streven. De Orde bestaat uit een groep personen van een grote pluriformiteit wat betreft deskundig. heid en waarde-opvattingen. Juist door die pluriformiteit kan er sprake zijn van een boeiende, lerende, dynamische gemeenschap. Maar dan blijft nog de klem. mende vraag bestaan: welke minimum eisen moet men stellen aan het lidmaat. schap om naar binnen en naar buiten toe, te kunnen spreken van een professio. nele organisatie? Criteria zijn moeilijk vast te stellen, maar de uitvoering van het toelatingsbeleid geeft aanknopingspunten.

\section{Toelatingsbeleid van de OOA}

Zoals het groene ledenboekje 1977 vermeldt:

„De Orde streeft naar een deskundig en maatschappelijk deugdelijke beoefening van de organisatiekunde in al zijn facetten. Daarbij rekent de vereniging het tot zijn taak de samenleving vertrouwd te maken met de verscheidenheid in de organisatorische problematiek en met het belang van het vinden van verant. woorde oplossingen daarvoor. Leden en andere geïnteresseerden worden steeds opnieuw gestimuleerd hun inzicht in deze wetenschap te vergroten.

De toelating van nieuwe leden is met veel waarborgen omkleed. Daardoor en door toezicht uit te oefenen op de naleving van gedragsregels wordt de profes. sionele status van de organisatiekundige beschermd."

Tot zover het ledenboekje.

Zoals bij elk systeem van kwaliteitsbeheersing het geval is, is het systeem op. timaal indien alle personen in Nederland die in aanmerking komen daadwerkelijk lid zijn of worden en degenen die niet in aanmerking komen niet toegelaten worden.

Naarmate een groter percentage van deskundige organisatie-adviseurs lid is, is de representativiteit van de Orde groter en kan de Orde meer voor haar leden, het vak en de samenleving bereiken.

Dankzij de groei van het ledental in de laatste jaren schat ik dat bijna de helft van het aantal Nederlanders, dat in aanmerking komt, lid is. Mede door de band met de Raad van Organisatie-Adviesbureaus, die kort geleden een belangrijke versterking heeft ondergaan door een uitbreiding van het aantal aangesloten bureaus, is mijns inziens de representativiteit van de OOA voor het beroep de laatste jaren versterkt.

Bij de uitvoering van het toelatingsbeleid wordt getracht te voorkomen dat personen worden toegelaten, die door ondeskundigheid of onmaatschappelijk gedrag de goede naam van de OOA in opspraak kunnen brengen. In dit verband moge artikel 2 van het reglement van toelating geciteerd worden:

„Om tot de Orde te kunnen worden toegelaten dienen aspirantleden aan te tonen, dat zij aan de verwezenlijking van de doelstelling(en) van de Orde kunnen bijdragen en daartoe:

1 over voldoende kennis beschikken van de algemene grondslagen van de organisatiekunde, ongeacht het eigen gespecialiseerde gebied, 
2 voldoende inzicht hebben in de samenhang van het eigen gespecialiseerde vakgebied, met andere gebieden der organisatiekunde,

3 bewezen hebben hun kennis van de organisatiekunde in de eigen beroepsuit. oefening in de praktijk te kunnen brengen,

4 in hun beroepsuitoefening voldoende zelfstandig zijn, en

5 voldoen aan de eisen van waardige beroepsuitoefening zoals aangegeven in de gedragsregels van de Orde."

Tot zover artikel 2 van het reglement van toelating van de OOA.

Hoewel getracht is om in artikel 2 een zo duidelijk mogelijke omschrijving te geven, kan het niet anders dan globaal blijven. Dit is temeer zo omdat deze tekst ook toepasbaar moet zijn op organisatiekundigen die niet als adviseur werkzaam zijn.

Om het toelatingsbeleid - ondanks deze globale tekst goed en rechtvaardig te kunnen uitvoeren, is gezocht naar een procedure waarbij enerzijds ruimte wordt geboden voor de pluriformiteit in de inzichten van de leden en anderzijds een leersituatie wordt geschapen, waardoor er van een dynamische ,normvinding” sprake is. In het volgende wordt vrij uitgebreid stilgestaan bij de uitvoering van het toelatingsbeleid om te laten zien, hoe moeilijk het is in de praktijk een oordeel te vellen over de gewenste minimale vakbekwaamheid van organisatie adviseurs.

\section{Uitvoering van het toelatingsbeleid}

Enige jaren geleden was de toelating vrijwel uitsluitend afhankelijk van het oor. deel van de leden van een vaste Commissie van Onderzoek (C.v.O.). In de huidige procedure die meer aan wensen van dynamiek en democratisering tegemoet wil komen, gaat de C.v.O. in eerste instantie af op het oordeel van drie leden van de OOA, die door het aspirantlid aangezocht worden als referenten op te treden. Zo mogelijk dient tenminste één van de 3 referenten werkzaam te zijn binnen het bureau, het bedrijf of de instelling waar het aspirantlid werkzaam is. Tenminste één referent dient van buiten de werkkring afkomstig te zijn. Sinds enige tijd wordt ook als eis gesteld dat de referenten niet alle drie vanuit dezelfde discipline het organisatievraagstuk benaderen. Hiermee wordt beoogd te voorkomen dat een te specialistisch oordeel wordt geveld, zodat de eerstgenoemde twee eisen van artikel 2 voldoende in acht genomen kunnen worden. Zo wordt het bijv. niet aanvaard dat de drie referenten voor een bepaald aspirantlid oorspronkelijk alle drie als agogen, accountants of als informatiespecialisten zijn opgeleid.

De Commissie van Onderzoek bestaat zelf uit drie benoemde leden bijgestaan door het secretariaat van de Orde. De C.v.O. oordeelt op basis van uitvoerige ad. viezen van elk van de referenten afzonderlijk en op grond van de door het aspirantlid ingevulde vragenlijst en een door hem gemaakt werkstuk. Vooral op overeenkomst en verschil tussen de adviezen van de drie referenten wordt gelet.

In de loop der jaren hebben de leden van de C.v.O. en een aantal leden die veelvuldig als referent optreden ervaring opgedaan. Op grond hiervan zijn de procedure en toetsingscriteria al lerend aangepast aan veranderende opvattingen omtrent de vakbeoefening en opleidingsvereisten. Hieruit is bijv. het verzoek aan aspirantleden voortgevloeid om, naast een curriculum vitae, een anoniem gemaakt werkstuk omtrent een recent eigen organisatie onderzoek en een eigen 
sterkte-zwakte-analyse van de uitoefening van het beroep in te leveren. Deze twee meer persoonlijke werkstukken kunnen als uitgangspunt voor gesprekken met de referenten dienen. Met het oog op de privacy worden deze werkstukken na af. ronding van de toelatingsprocedure vernietigd. Om aan de lezer inzicht te geven op grond van welke maatstaven de vakbekwaamheid getoetst wordt, zal in het volgende hoofdstukje nader ingegaan worden op de indeling en vragen van het formulier, dat door iedere referent afzonderlijk wordt ingevuld.

\section{Toetsing van de vakbekwaamheid van aspirantleden door referenten van de OOA}

De vragen richten zich achtereenvolgens op ervaring, kennis en inzicht, en op de beroepsopvatting.

Wat betreft de ervaring stelt de OOA de volgende eisen voor het gewone lid. maatschap. „De ervaring moet - in combinatie met de opleiding - zodanig zijn, dat het aspirantlid in staat is eigen verantwoordelijkheid te dragen als zelfstandig projektleider voor een organisatieonderzoek/adviesprojekt van enige omvang en daarbij eventuele gespecialiseerde kennis/vaardigheid kunnen integreren in de samenhang van algemene praktische organisatieproblematiek. Hoewel het moeilijk is voor de ervaring een objectieve maatstaf te geven, lijkt 5 jaar een bruikbare richtlijn."

Wat betreft kennis en inzicht stelt de OOA aan gewone en aan kandidaatleden dezelfde eisen. Uitgegaan wordt van een opleiding op academisch niveau, eventueel aangevuld met post-academiaal onderwijs. Als maatstaf wordt de opleiding van de Stichting Interacademiale Opleiding Organisatiekunde gehanteerd. Verderop in dit artikel wordt nader ingegaan op het programma van de SIOO. De programma's van een aantal andere opleidingen zijn bekeken. Dit heeft er tot nog toe toe geleid, dat volgens het reglement van toelating, naast SIOO ook de Bedrijfskundeopleidingen Interfaculteit Delft, TH-Eindhoven en TH-Twente en de Opleiding In. terne Organisatie-Adviseur N.V. Philips voldoen aan de eisen.

Als het aspirantlid geen van deze opleidingen gevolgd heeft moet op andere wijze aannemelijk gemaakt worden dat het niveau van kennis en inzicht voldoende is.

Evenals bij kennis en inzicht het geval is, maakt de Orde geen onderscheid tus. sen de gewenste beroepshouding van gewone en kandidaatleden. Volgens het formulier moet het lid zich in zijn werk kritisch en onafhankelijk opstellen, een professionele houding hebben. Tot de beroepshouding rekent men o.a. het zich willen houden aan de opvattingen zoals die in de gedragsregels van de Orde zijn neergelegd. Het is duidelijk dat het beoordelen van de beroepshouding erg moeilijk is. In dit verband is het een goede zaak dat sinds kort de gedragsregels door de toelichting verder geëxpliciteerd zijn, zoals elders in dit nummer besproken wordt. In het volgende zal het zoeklicht vooral gericht worden op de elementen kennis en inzicht, voorzover die door een aantal formele opleidingen in Nederland aangereikt worden en van nut zijn voor het funktioneren van organisatieadviseurs op het niveau, dat van OOA-leden geëist wordt. 


\section{Opleidingen in het algemeen}

Zoals in het voorgaande is gesteld, blijft de aard en het niveau van de formele opleiding van een persoon een voorname rol spelen bij het beoordelen van zijn vakbekwaamheid.

In navolging van Bos $\left.{ }^{11}\right)$ kan het begrip opleiding als volgt in verband gebracht worden met training en vorming. Met onderstaand beeld wordt uitgedrukt, dat elke opleiding ook training omvat en dat elke vorming ook opleiding, inclusief training omvat.

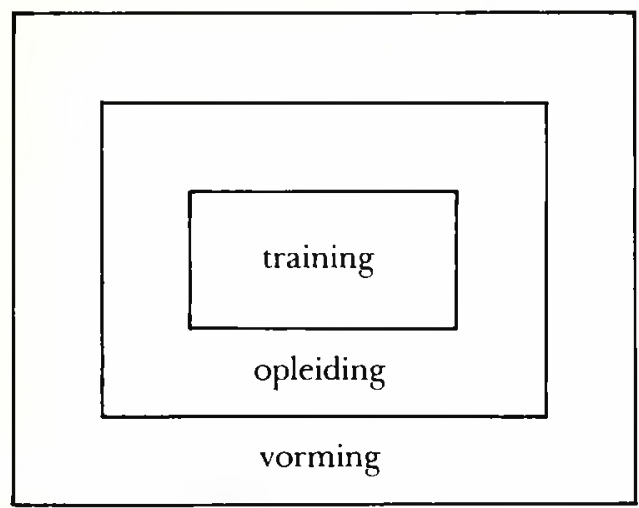

Schema 1. Verband tussen training, opleiding en vorming volgens drs. A. H. Bos ${ }^{\prime \prime}$ )

Bij training is er sprake van het inoefenen van elementaire kennis en vaardigheden, zodat deze als het ware „automatisch" ter beschikking staan. Waar het om kennis in de eigenlijke zin en om begrip gaat, is van buiten leren of automatisch uitvoeren alleen niet voldoende. Bij opleiding gaat het daarom om inzicht te laten verkrijgen in het hoe en waarom, om het geleerde ook zelfstandig in omstandig. heden te kunnen toepassen die nieuw zijn, die tijdens de opleiding niet behandeld zijn. Bij opleiding vindt er integratie plaats tussen verschillende kennisgebieden. Opleiding heeft daarom te maken met een groter gebied dan training, maar bevat altijd onderdelen die getraind moeten worden.

Bij elke leeractiviteit is ook een vormend element aanwezig en integratie van de kennis in de persoonlijkheid van de totale mens. Dit betekent dat niet alleen het intellectuele weten en denken worden ontwikkeld, niet alleen vaardigheden, maar dat ook aan de ontwikkeling van het gevoels- en wilsleven aandacht wordt besteed (fantasie, oordeelsvermogen, sociaal gevoel, innerlijke zekerheid, mora liteit, verantwoordelijkheid e.d.).

Al deze kanten van de persoonlijkheid hangen met elkaar samen en bepalen de instelling, de levensbeschouwing en het gedrag van mensen. Tot zover Bos.

Bij het beoordelen van een opleiding is het van belang ook rekening te houden met de trainings- en vormingselementen. In het algemeen valt bij universitaire opleidingen de nadruk op wetenschappelijke kennis en inzicht. Bij Hogere Beroeps Opleidingen, zoals HTS, de HEAO en de Sociale Academie wordt veel aan. dacht besteed aan de training van vaardigheden. Bij de militaire opleidingen KMA en KIM en bij het NOIB te Breukelen treedt de wetenschappelijk analytische benadering sterker op de voorgrond, terwijl ook expliciet vormingselementen een rol spelen. Mede ten gevolge van de korte duur van de studie is het moeilijk 
- zonder verdere formele opleiding - het doctorale niveau te bereiken, dat vereist wordt voor toelating tot de OOA. Door de keuze van de didactische vorm en de intense begeleiding van het leerproces komt bij de postacademiale opleidingen voor organisatie-adviseur, te weten het SIOO en de interne cursus van Philips, ook de vorming sterk aan bod.

In het navolgende zal bij de bespreking van opleidingen voornamelijk gekeken worden naar de aangeboden kennispakketten. Eerst zal een aantal enigszins mono-disciplinaire universitaire studies bekeken worden, waarna de bedrijfskundige opleidingen volgen. Als laatste wordt het SIOO en de vergelijkbare opleiding van Philips in het zoeklicht geplaatst. Er is van afgezien andere postacademiale opleidingen, zoals bijvoorbeeld door de Stichting Bedrijfskunde verzorgd wordt, te bespreken, omdat deze geen van alle specifiek zijn voor de opleiding tot organisatie adviseur.

Voor een goed begrip van de opleidingen wordt eerst de aandacht van de lezer gevraagd voor verschillende benaderingen van organisatie-vraagstukken.

\section{Alternatieve benaderingen van organisatie-vraagstukken}

Organisaties zijn te beschouwen:

- als systemen van mensen en middelen, of

- als gemeenschappen van mensen, of

- als coalities van belangengroepen,

die in wisselwerking met de omgeving,

gericht zijn op het realiseren van een samenhangend pakket doelstellingen.

In navolging van Leavitt $\left.{ }^{12}\right) \mathrm{kan}$ met Hand $\mathrm{y}^{13}$ ) sterk vereenvoudigd gesteld wor. den, dat voor het oplossen van - in een bedrijfssituatie - gerezen problemen elk van de drie volgende hoekpunten zich als aangrijpingspunt leent.

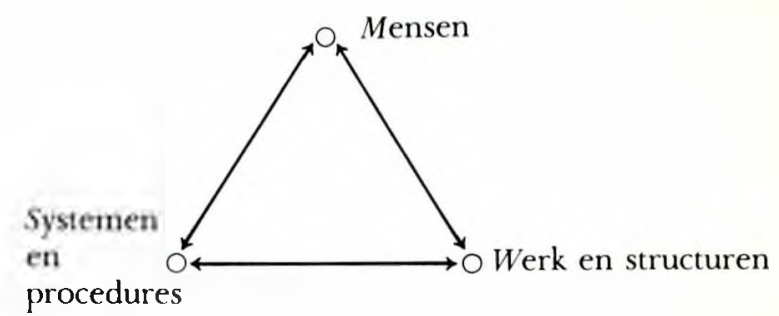

Schema 2. Aangrijpingspunten voor onderzoek en verandering van organisaties (Handy $\left.{ }^{13}\right)$ )

Men realisere zich echter goed dat in welk hoekpunt men ook begint, de andere hoekpunten mede beïnvloed worden. Historisch gezien zijn bijv. organisatie-ingenieurs begonnen vanuit hoekpunt $\mathrm{W}$ te werken, accountants en bedrijfseconomen vanuit $S$ en organisatiepsychologen (en -sociologen) vanuit $M$.

De drie variabelen zijn uiterst nauw met elkaar verbonden en liggen ingebed in een omgeving. Als omgeving kan de eigen organisatie, de industrie, de markt of de gehele samenleving beschouwd worden. Er zijn veel aspecten van de omgeving die voor de betreffende bedrijfssituatie van belang kunnen zijn.

Als belangrijkste factoren die op de grens van binnen en buiten liggen en slechts op langere termijn veranderd kunnen worden, zijn te noemen: cultuur, technologie en doelstellingen. Handy geeft het verband met de vorige figuur als volgt weer: 


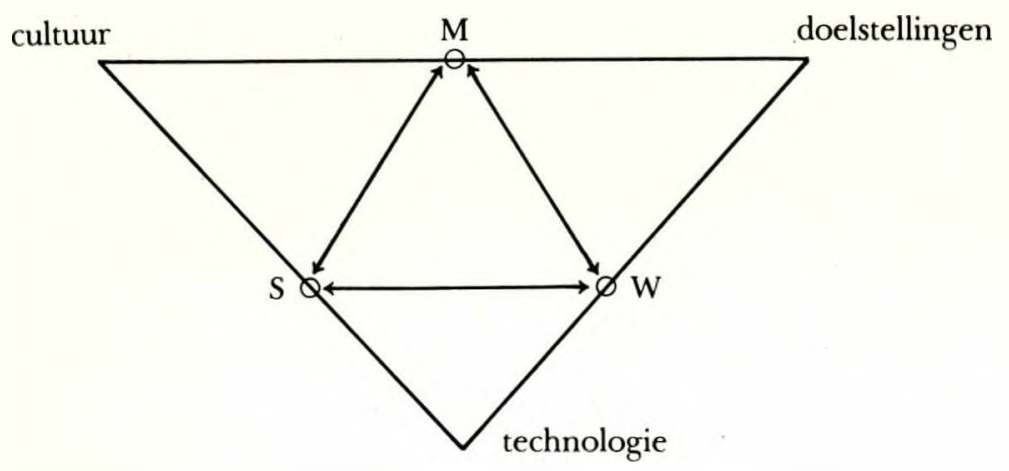

Schema 3. Samenhang tussen een aantal factoren die de gang van zaken in een bedrijfssituatie bepalen (Hand (') $\left.^{3}\right)$

Hieruit kan men bijvoorbeeld aflezen, dat doelstellingen nagestreefd kunnen worden met behulp van systemen en procedures via mensen of via de structurering van werk, waarbij rekening gehouden moet worden met de geldende cultuur en de stand der technologie.

In het kader van dit artikel is het niet nodig verder op de betekenis van de fi. guur in te gaan. Duidelijk is, dat elke bedrijfssituatie een complex geheel is. Vele optieken zijn daarom nodig om het gehele systeem enigermate te kunnen be. schrijven en verklaren, laat staan om de effecten van interventies te kunnen voor. spellen. Het is daarom geen wonder dat er in Nederland zovele universitaire studierichtingen zijn waarbinnen men een specialisatie op het gebied van organisatie kan kiezen.

\section{Specialisatie op het gebied van organisatiekunde binnen diverse afdelingen en faculteiten in $\mathrm{Ne}$ - derland}

Er zijn veel „mono-disciplines” in Nederland, waarin het voor studenten mogelijk is tijdens het doctoraal een specialisatie te kiezen op het gebied van organisatie. kunde. Aansluitend op schema 2 van Handy zal in het kort iets gezegd worden over de studiemogelijkheden op het gebied van organisatie- c.q. bedrijfskunde binnen de

- technische wetenschappen,

- economie,

- psychologie en

- sociologie.

Dit neemt niet weg dat ook in andere studierichtingen organisatiekunde op een of andere wijze naar voren komt. Te denken valt bijv. aan de ontwikkeling in de richting van bestuurskunde vanuit recht en politicologie. Ook bij studies als zie. kenhuiskunde en onderwijskunde speelt organisatiekunde een rol. Na dit hoofd. stuk worden de multi-c.q. interdisciplinaire bedrijfskundige opleidingen vermeld, waarbij uiteraard organisatiekunde één van de centrale vakken vormt.

\section{Organisatiekunde binnen de technische wetenschappen}

Wat de technische wereld betreft is het organisatiegebied vooral ontwikkeld van. uit de Werktuigbouwkunde en in het bijzonder vanuit de "Werkplaatstechniek”. 
De traditie van Taylor volgend, hebben in Nederland ingenieurs als Hijmans, Be. renschot, Volbeda, IJdo en Bosboom zich van oorsprong beziggehouden met de vraag hoe je het man-machine-systeem optimaal ontwerpt, organiseert en het werk voorbereidt, plant en beheerst. Een start dus vanuit het rechter hoekpunt van de kleine driehoek van Handy (figuur 2). Zoals figuur 3 suggereert, wordt het werk georganiseerd met een duidelijk doel (de gewenste output) voor ogen en met gebruikmaking van een grondige kennis van de laatste stand der technologie.

$\mathrm{Bij}$ de technische wetenschappen speelt vooral het ontwerpen een grote rol. Beoogd wordt alternatieven te ontwikkelen, waarmee doelstellingen bereikt kun. nen worden. Men werkt sterk doelgericht. Het gaat vooral om de effectiviteit van de middelen. In navolging van de natuurwetenschappen denkt men in termen van oorzaak en gevolg, terwijl een hiërarchie van doel en middelen vaak dient als impliciet uitgangspunt. Bij technici gaat het vooral om het creëren van alternatieven die daadwerkelijk tot het beoogde doel leiden. Dit in tegenstelling tot economen bij wie het zwaartepunt ligt bij het evalueren van aangeboden alternatieven, met geld als gemeenschappelijke noemer.

Binnen de afdelingen Werktuigbouwkunde van elk der drie TH's vormt werk. plaatstechniek nog steeds een belangrijke specialisatiemogelijkheid. Bij de $\mathrm{TH}$ te Eindhoven heeft de vakgroep Werkplaatstechniek de stoot gegeven tot het ontstaan van de afdeling der Bedrijfskunde, waarop later teruggekomen zal worden. Aan de TH te Twente is een dergelijk verband ook aan te wijzen.

In Delft heeft een andere ontwikkeling plaatsgevonden. Tegen het eind van de zestiger jaren is een leerstoel Industriële Organisatie $\left.{ }^{14}\right)$ ingesteld binnen de afde. ling Werktuigbouwkunde en de thans genoemde afdeling voor Luchtvaart- en Ruimtevaarttechniek. Ook binnen de afdelingen Civiel en Wiskunde (Informatica) zijn vergelijkbare leerstoelen aanwezig.

Bij de studierichting Industriële Organisatie krijgt de student na zijn kandidaats. examen de mogelijkheid zich binnen zijn eigen technische afdeling de laatste twee jaar geheel op de organisatiekunde te concentreren. Mede door het aanbod van vakken verzorgd door de afdeling der algemene wetenschappen, kan de student tezamen met zijn begeleider een breed keuzepakket samenstellen, waarin ook vakken als economie, sociologie en psychologie vertegenwoordigd moeten zijn. Ondanks deze specialisatie verkrijgt men bij afstuderen de titel van werktuig. bouwkundig ingenieur.

Niet alleen vanuit werkplaatstechniek maar ook vanuit meet en regeltechniek en de wiskunde (informatica) zijn aan de drie TH's en te Groningen ontwikkelingen te constateren op het gebied van systeemleer, operationele research en or. ganisatiekunde.

Niet onvermeld mag blijven dat eveneens binnen de technische wetenschappen te Wageningen een specialisatie mogelijk is op het gebied van organisatie. Hierbij wordt zowel een aanzet gegeven tot bedrijfskunde als bestuurskunde.

\section{Organisatiekunde binnen de economische facultelten}

$\mathrm{Bij}$ de economische wetenschappen bestaat een lange traditie op het gebied van organisatiekunde. Dit vak komen we onder de benamingen ,interne organisatie”, „organisatie en leiding" e.d. tegen. Daarnaast zijn er verbijzonderingen zoals produktie-organisatie en commerciële organisatie. 
In het bijzonder bij de opleiding in accountancy, spelen administratieve orga nisatiekunde en financiering een grote rol. Mede gestimuleerd door de econometrie heeft evenals bij de technische hogescholen de kwantitatieve benadering van organisatie-vraagstukken binnen bedrijven aandacht gekregen (bedrijfs.eco. nometrie).

Met behulp van vakken als staathuishoudkunde, staats. en administratief recht e.d. is het ook mogelijk om binnen de studie der economie een aanzet tot bestuurskunde te geven.

In het algemeen kan gesteld worden dat de opleiding dichter ligt bij bedrijfs. kunde dan bij organisatiekunde. Uitgaande van economische doelstellingen wordt nagegaan welke systemen en procedures optimaal zijn om deze doelen zo efficiënt mogelijk te bereiken. Mensen en technologie worden vaak slechts als be. perkende randvoorwaarden opgevat. Een goed voorbeeld van de benadering van organisatie-vraagstukken door economen vormt de recente publicatie van Eyzen. ga en andere auteurs „Planning en beheersing van organisaties" ${ }^{\prime 5}$ ).

\section{Organisatiekunde binnen de (sub)faculteiten der psychologie}

De voornaamste invalshoek vanuit de psychologie bestond oorspronkelijk uit de selectie en training van mensen om door een organisatie gewenste posities zo goed mogelijk te vervullen. Evenals bij de technische en economische wetenschappen dikwijls het geval is, werd in die periode de mens dus vooral als produktiemiddel, werkende als uitvoerende op de fabrieksvloer of als administratie. ve kracht beschouwd. Deze gedachtenlijn vanuit de „human relations” school vindt men in wat andere vorm nog steeds terug. Bij de ergonomie wordt doel. bewust gezocht naar het ontwerpen van een (fysieke) werkomgeving, van produk. ten of gereedschappen met de mens als uitgangspunt.

Onder invloed van de humanistische psychologie is men de mens meer en meer gaan zien als bron (resource) van creativiteit. Door de mens zich te laten ontplooien en inspraak te geven, zal hij ook mee kunnen denken en doen aan het adequaat laten functioneren en verbeteren van organisaties ${ }^{16}$ ).

In de psychologie wordt de laatste tijd ook veel aandacht gegeven aan de wijze waarop de mens tot besluiten komt - individueel en als lid van een groep. Informatie-verwerving en -verwerking spelen daarbij een grote rol. Niet alleen informatie in deze zin, maar ook het brede gebied van communicatie behoort tot het studieveld van de psycholoog. Veel psychologen hebben zich bezig gehouden met leiderschapstheorieën. Het leren krijgt daarbij veel aandacht en dat niet alleen van individuen maar ook van (kleine) groepen. Hiermee komt naast ,manage ment development", organisatie ontwikkeling binnen het gezichtsveld van de psy. choloog.

In het algemeen, kan men stellen dat bij de benadering van organisaties door psychologen het procesmatige benadrukt wordt. Organisatiekunde, „veranderkunde” en conflict-beheersing nemen vooral bij vakgroepen als sociale psychologie en arbeids- en organisatie psychologie een centrale plaats in. De mens vormt zowel een bron, als een doel van het organiseren. Een tiental jaren geleden werd arbeidssatisfactie als één van de centrale doeleinden aangemerkt. Thans spreekt men meer van persoonlijk effectief functioneren en verantwoordelijkheidsverruiming. 


\section{Organisatiekunde binnen de (sub-)faculteiten der sociologie}

In tegenstelling tot de psychologie, waarbij de individuele mens als uitgangspunt dient, vormen bij sociologie de (grote) groep en de structuren het object van studie. Vooral de spanning tussen een organisatie en de omgeving, en tussen organisaties onderling krijgen veel aandacht. Institutionaliseringsprocessen, macht en legitimiteit zijn hierbij veel gebruikte begrippen. Deze begrippen zijn ook belangrijk voor het begrijpen van professionaliseringsverschijnselen.

In de moderne literatuur op het gebied van organisatiekunde spelen sociolo. gen een grote rol. In Nederland kunnen we vakgroepen tegenkomen onder benamingen als bedrijfs-, bestuurs-, beleids- en organisatie sociologie.

Evenals bij psychologie het geval is, krijgt vooral de procesmatige benadering veel aandacht. Sociale psychologie vormt een soort brugfunctie tussen sociologie en psychologie, met name waar het gaat om het implementeren van veranderingen en het veranderen van organisaties. Een illustratie hiervan vormt organisatie-ontwikkeling.

Ook de socio-technische benadering is vooral vanuit de sociologie op gang gekomen. Thans wordt die benadering veelal beschouwd als een onderdeel van de theorieën omtrent systemen.

\section{Conclusies t.a.v. specialisaties op het gebied van organisatiekunde binnen diverse afdelingen en faculteiten}

Drie hoofdstromingen kunnen hierbij worden onderscheiden, te weten

- de technisch.economische benadering van organisaties als functionerende systemen, en

- de gedragswetenschappelijke benadering van organisaties als gemeenschap. pen van mensen, c.q.

- als coalitie van belangengroepen, dus als politiek systeem.

In de vier behandelde wetenschappen is een inhoudelijke en een procesmatige benadering te onderkennen. Ideaal typisch kunnen de volgende typeringen ter onderscheiding gegeven worden.

Inhoudelijk vormen binnen organisaties, de volgende functionele gebieden het voornaamste object van onderzoek:

technisch: - produktie, speurwerk en ontwikkeling

economisch: - marketing, financiering

psychologisch: - personeelszaken

sociologisch: - personeelszaken (en beleidsvragen, zoals t.a.v. de arbeidsmarkt)

Primair worden nagestreefd:

technisch : effectiviteit

economisch : efficiency

psychologisch : (arbeids-)satisfactie (c.q. menselijk functioneren)

sociologisch : legitimiteit

Procesmatig worden vaak de volgende benaderingen toegepast:

technisch : ontwerpen van alternatieven

economisch : evalueren van alternatieven op basis van geld

economisch/technisch: ontwerpen van informatie systemen en procedures voor het besturen en beheersen 
psychologisch : begeleiden van leerprocessen van personen en kleine groepen sociologisch : organisatie-ontwikkeling en analyse van machtsstructuren.

In bovenstaande mono-disciplines wordt met opzet een enigszins eenzijdige optiek gekozen van de benadering van het organisatievraagstuk. Dit heeft enerzijds het voordeel dat dieper op die benadering ingegaan kan worden en een „erkend wetenschappelijk" niveau bereikt kan worden. Anderzijds bevatten deze studies veel zaken die wel voor de betreffende (mono-)discipline, maar niet direkt voor een organisatie adviseur van belang zijn. In het algemeen kan gesteld worden dat bovengenoemde specialisaties uitstekende aanzetten vormen voor een bepaalde organisatie-analyse. Tot dusver is niet onderzocht in hoeverre de kennis en het inzicht die in deze studies worden verkregen voldoende kunnen worden geacht om hiermee tot de OOA te worden toegelaten. Een van de vraagpunten zal m.i. de breedte vormen.

In tegenstelling tot de doelbewuste eenzijdigheid van bovenstaande studies proberen de in het volgende te behandelen bedrijfskundige opleidingen een meer evenwichtige benadering te geven, waarbij bovenstaande optieken afzon. derlijk en in samenhang aan bod komen.

\section{Bedrijfskundige opleidingen in Nederland}

In Nederland bestaan twee opleidingen die tot de titel bedrijfskundig ingenieur voeren (Eindhoven en Twente) en twee die tot de titel doctorandus bedrijfskunde voeren (Rotterdam/Delft en Groningen). In de vermelde volgorde zijn deze opleidingen gesticht, waarbij aangetekend kan worden dat de opleiding in Groningen pas begin 1978 officieel geopend is.

De bedrijfskundige opleidingen hebben gemeen dat getracht wordt de orga. nisatie op inter-, of multi-disciplinaire wijze te bestuderen. Verschillen zijn, dat de student aan de $\mathrm{TH}$ te Eindhoven (THE) direkt met de opleiding begint, in Groningen voorlopig na 1 jaar propadeuse, terwijl in Twente (TH-T) en Delft sprake is van een post-kandidaats-studie. Aan de TH.T is een technisch kandidaats nodig, terwijl voor toelating aan de Interfaculteit Bedrijfskunde te Delft (IB) naast techniek ook een kandidaats economie, rechten of kwantitatieve en sociale weten. schappen als basis kan dienen. De IB neemt bovendien een aanvullend kandidaats-examen af bestaande uit tentamens in de vijf genoemde vakgebieden voor toelating tot de doctorale fase. Onder „kwantitatieve wetenschap” wordt hierbij „wiskunde en statistiek" verstaan.

Het verschil tussen bedrijfskundig ingenieur en doctorandus is waarschijnlijk kleiner dan de meeste buitenstaanders denken. Bij de ingenieur is er de garantie van een vrij diepgaande kennis van kwantitatieve en technische zaken, terwijl dat bij de doctorandus in mindere mate het geval is. Bij de afgestudeerden van de IB is grote verscheidenheid aan oriëntaties aanwezig, mede door de verschillende vooropleidingen tijdens het kandidaats. Daar in Groningen pas na 4 à 5 jaar de eerste afgestudeerden tegemoet gezien kunnen worden, is nog weinig over die studie te zeggen. Evenals bij de andere studies het geval is, zal ook hier door het instellen van keuzepakketten aan de behoefte aan verscheidenheid voldaan kunnen worden. 
Aan de studiegidsen van de bedrijfskundige opleidingen kan het volgende ontleend worden.

\section{TH-Eindhoven, afdeling der Bedrifskunde}

„De opleiding is gericht op maatschappelijke functies, waarbij onderzoek en/of besturing van technisch-sociale systemen centraal staan. In de studie spelen de na tuurwetenschappen, de gedragswetenschappen en de technische wetenschappen een rol. Het bedrijf (en daaronder mede verstaan de instelling), zowel het particuliere als dat van de overheid, is een systeem waarvan het totale rendement niet alleen door de hoedanigheid van de afzonderlijke onderdelen wordt bepaald, maar ook door de wisselwerking tussen mensen, machines en materialen. De be drijfskundig ingenieur bestudeert dit systeem, analyseert het en kan het vervol. gens verbeteren.

Hij wordt opgeleid om nieuwe systemen te ontwerpen en de wegen voor de uitvoering van die ontwerpen aan te geven. Toch is de bedrijfskundig ingenieur geen specialist op technisch-constructief, economisch of sociologisch terrein. $\mathrm{Hij}$ is op de hoogte van de opvattingen van sociale, psychologische, economische en organisatorische wetenschappen over het bedrijf. Hij kan deze verschillende dis. ciplines aanwenden om praktische problemen op te lossen en/of fundamentele vraagstukken in samenwerking met anderen te onderkennen en te onderzoeken. De bedrijfskundig ingenieur is in de eerste plaats ingenieur, dat wil zeggen hij is een academisch gevormd technicus, die geleerd heeft wetenschappelijke metho. den toe te passen bij het bestuderen van een bedrijf als geïntegreerd geheel en die daaraan door eigen creativiteit mede richting kan geven.

In bedrijven, zowel industriële als dienstverlenende, zowel particuliere als van de overheid, bestaat behoefte aan deze functionarissen. De taken en de mogelijk heden zijn velerlei en zeker niet beperkt tot het ontwerpen en ontwikkelen van produktiesystemen. Vele academici zijn nu reeds betrokken bij de analyse, het ontwerp en de bestudering van het bedrijf als geheel of bij een deel daarvan. In het bijzonder met het oog op die taken is de opleiding tot bedrijfskundig ingenieur ter hand genomen. Zij beoogt een meer gerichte voorbereiding op het vervullen van die groep specialistische functies en bedrijfsfuncties, die thans reeds door ingenieurs worden vervuld, zoals:

- functies op het gebied van planning, organisatie en efficiency, inrichting van werk en arbeidsplaatsen;

- technisch-sociale en technisch-commerciële brugfuncties;

- afdelingshoofd of bedrijfsleider van kleinere produktie eenheden;

- medewerkers van raadgevende ingenieursbureaus;

- onderzoekers op het gebied van bedrijfskundige problematiek."

\section{TH-Twente, afdeling der Bedrijfsunde}

„De doctorale studie kan worden gevolgd door hen die zich willen voorbereiden op functies van bestuur en beheer. Aangezien deze functies een multidisciplinaire benadering van gewoonlijk complexe vraagstukken vereisen, besteedt de opleiding bijzondere aandacht aan verdieping van sociale, bedrijfseconomische, juridische en psychologische inzichten, terwijl reeds verworven technisch-kwantita. tieve kennis operationeel wordt versterkt en toegepast op bedrijfskundige vraag. stukken. 
In het gehele programma van de afdeling der bedrijfskunde wordt het begrip „bedrijf" opgevat als een open systeem van menselijke talenten en materiële mid. delen, dat zijn reden van bestaan ontleent aan de maatschappelijk doelmatige voortbrenging of distributie van goederen of diensten van welke aard dan ook. Deze definitie omvat zowel private, openbare en coöperatieve bedrijven, alsmede andere vormen van organisatie ten dienste van het bevredigen van maatschap. pelijke behoeften met schaarse middelen. De verhouding van de organisatie tot de maatschappij waarin zij opereert, vormt een belangrijk aspect van het studieprogramma. Een zekere mate van keuzevrijheid in het studiepakket geeft mogelijkheden tot het leggen van accenten in de belangstellingssfeer van de student. Nog sterker geldt dit voor de afstudeeropdracht, waarin men de nadruk kan leg. gen op onderwerpen als financiering, marketing, beslissingsmodellen, organisatiestructuur, kwaliteitsbeleid, sociaal-economische politiek, de mens in het bedrijf, informatica, systeemanalyse, fusies, juridische structuur, ontwikkelingslanden, in. dustriële democratie en vele andere."

\section{Interfaculteit Bedrifskunde, gevestigd te Delft (vroeger Rotterdam)}

„Bedrijfskunde wil zeggen, het op wetenschappelijk niveau verwerven en verwer ken van kennis en vaardigheden, die nodig zijn om begrijpend en handelend te kunnen inspelen op problemen en mogelijkheden in (al of niet op winst gerichte) organisaties. Bedrijfssituaties worden niet geïsoleerd bezien, maar in hun maat. schappelijke context geplaatst.

De bedrijfskundestudent(e) geraakt tijdens de studie vertrouwd met de operationele aspecten van de bedrijfswetenschappen, zodat hij/zij met de vele specialisten in zijn toekomstig arbeidsveld op een adequate wijze kan samenwerken. De studie draagt een interdisciplinair karakter.

Het totale programma duurt $2 \frac{1}{4}$ jaar, en bestaat uit een Adaptatie Fase, gevolgd door een Doctorale Fase. De Adaptatie Fase vormt de voorbereiding op de Doctorale Fase.

Tot de doctorale studie kan men worden toegelaten indien men met goed gevolg het kandidaatsexamen in één of meer van de volgende studierichtingen heeft afgelegd: economie, recht, techniek, kwantitatieve en sociale wetenschappen. (Onder bepaalde voorwaarden kunnen ook andere kandidaten(tes) worden toegelaten.) De IB neemt een aanvullend kandidaatsexamen af bestaande uit ten. tamens in de hierboven genoemde vakgebieden.

De Doctorale Fase.

De studie in de Doctorale Fase duurt twee jaar en bestaat uit vijf probleemgebie den ( 45 weken), drie interimperioden ( 20 weken) en een afstudeerperiode ( 15 we. ken).

Hoewel binnen de probleemgebieden wel keuze mogelijkheden bestaan, vormen zij toch de gemeenschappelijke kern van de opleiding. De probleemgebieden zijn:

PG.0 Verwerving en verwerking van informatie

Inleiding tot de methoden voor verwerving van informatie en de bouw van formele modellen ten behoeve van representatie van aspecten van orga nisatie en hun omgeving.

PG.1 Omgevingsverkenning

Beschrijving en analyse van de structuur en het interne gedrag van afzon. 
derlijke organisaties, gericht op het begrijpen van het functioneren daarvan.

PG.2 Analyse van de organisatie

Beschrijving en analyse van de structuur en het intern gedrag van afzonderlijke organisaties, gericht op het begrijpen daarvan.

PG-3 Het interne organisatieproces

De besturing en beheersing van een organisatie en de voorbereiding en uitvoering van haar activiteiten op korte termijn.

PG.4 Inter-organisatie processen

De ontwikkeling door een organisatie van activiteiten op lange termijn, ter beïnvloeding van het proces van de wisselwerking met andere organisaties.

Interimperioden.

Naast de op integratie gerichte benadering van de probleemgebieden, wordt de mogelijkheid geboden tot differentiatie, zowel naar voorkennis als naar interesse. De differentiatie wordt bewerkstelligd in de zogenaamde in. terimperioden tijdens welke gelegenheid bestaat deel te nemen aan diverse keuzevakken en/of opdrachten.

Deze laatsten bestaan uit projekten van één of meer studenten(es), waar. bij gewerkt wordt aan een probleemstelling uit de praktijk en waarbij de vaardigheden en de kennis, verworven in de voorafgaande probleemgebie. den worden toegepast.

Het is gedurende deze interimperioden, dat de student(e) zich kan ont. wikkelen in o.m. marketing, produktie, financiering, bestuurskunde, onder. zoek etc.

\section{Afstudeerperiode.}

De doctorale studie wordt afgesloten met een afstudeerprojekt. Middels dit projekt dient de student onder begeleiding een projekt uit te voeren op een zodanige wijze dat zijn bedrijfskundige kennis toegepast wordt op een aan de empirie ontleende probleemstelling, zodanig dat een integratie van de verschillende, voor een bepaald probleem relevante aspekten, tot stand komt.

Nadat men met goed gevolg de studie heeft doorlopen, wordt het doctoraal diploma verleend dat recht geeft op de titel bedrijfskundig doctoran. dus."

\section{Konklusies t.a.v. bedrijfskundige opleidingen in Nederland}

In het bovenstaande zijn citaten opgenomen uit drie opleidingen. Groningen is weggelaten, omdat die opleiding pas in 1978 officieel gestart is. De drie citaten hebben betrekking op enigszins verschillende aspekten. Bij alle drie is er sprake van een wetenschappelijke opleiding waarbij de uitoefening van een beroep als belangrijke doelstelling geldt. Bij de TH's ligt het zwaartepunt op het beroep van ingenieur, bij de IB oorspronkelijk op „manager”, terwijl thans op de IB een bre. der scala mogelijk is gemaakt. Sedert voorjaar 1977 is het b.v. mogelijk een zgn. bestuurskundige variant te kiezen.

In alle opleidingen wordt veel inzicht in het functioneren en het ontwerpen, 
of veranderen van organisaties geboden. Het adviesproces komt slechts summier aan bod, maar kan b.v. aan de IB als keuzevak gevolgd worden. Gezien de breedte en de diepgang van de opleiding t.a.v. organisatorische vraagstukken is in 1977 door de OOA besloten, dat het kennispakket verkregen via een van deze drie bedrijfsopleidingen een voldoende kennis-basis biedt voor een funktie of beroep als interne of externe organisatie-adviseur. In beginsel kunnen afgestudeerden wanneer zij althans in hun werk op direkte of indirekte wijze als organisatiekundige of als organisatie adviseur werkzaam zijn, in aanmerking komen voor het kandidaatlidmaatschap van de OOA. Andere opleidingen hebben (nog) geen aanvraag bij de OOA ingediend en zijn dus niet als zodanig beoordeeld.

\section{Postacademiale opleidingen op het gebied van organisatie-advieskunde}

Thans zijn er twee postacademiale opleidingen in Nederland die een gerichte opleiding trachten te geven tot het beroep van organisatie-adviseur, zoals gedefinieerd door de OOA. Deze opleidingen zijn:

- De Stichting Interacademiale Opleiding Organisatiekunde, het SIOO, te Utrecht, en

- de opleiding Interne Organisatie-Adviseur (IOA) van Philips te Eindhoven.

Deze opleidingen zijn begonnen in 1958 en 1972 respectievelijk. Uit een brief dd. 29-4-1977 van de Commissie Toetsing Opleidingen aan het bestuur van de OOA, ontlenen wij het volgende t.a.v. de IOA.cursus van Philips.

„Thans is de achtste cursus bijna afgerond. Elke cursus groep bestaat uit 12 deel nemers. De IOA cursus is vrij exact - inhoudelijk - opgezet naar het SIOO-model. Dit is mede gebeurd omdat de SIOO-opleiding niet meer dan ca. acht Philips-medewerkers per jaar wil opnemen. De overeenkomst met de SIOO-opleiding heeft niet alleen betrekking op de inhoud van de cursus maar ook op het aantal belastinguren. De samenstelling van de IOA-cursusgroepen is interdisciplinair." Tot zover dit citaat.

In verband met de grote overeenkomst met het SIOO, wordt in het volgende slechts aandacht besteed aan het SIOO.

\section{Stichting Interacademiale Opleiding Organisatiekunde (SIOO)}

In de brochure voor de cursussen 33 en 34 die in augustus 1978, resp. in januari 1979 zullen starten, staat het volgende vermeld:

„Doelstelling van de opleiding.

De Stichting Interacademiale Opleiding Organisatiekunde (SIOO) stelt zich onder meer tot doel het geven van een na-ervaringsopleiding in de organisatiekunde.

Met deze opleiding wordt er naar gestreefd de deelnemers een brede en alge. mene vorming op academisch niveau te geven op het gebied van de organisa. tiekunde, waarbij het functioneren van de organisatie-adviseur in de beroepsprak. tijk centraal staat.

De opleiding is in de eerste plaats bestemd voor degenen die zich willen voor. bereiden op meer omvattende verantwoordelijkheden in het organisatie-advies. werk. Voor hen is de opleiding de beroepsopleiding. Zij zijn werkzaam in externe adviesbureaus en in interne adviesfuncties bij het bedrijfsleven, de overheid en 
non-profit-organisaties.

In de opleiding bestaat beperkte plaatsingsmogelijkheid voor anders georiën teerde organisatiekundigen (managers, personeelschefs, wetenschapsbeoefenaren, e.d.).

In en rond de beroepsuitoefening doen zich voortdurend nieuwe ontwikkelingen voor. In de opleiding vinden de deelnemers een basis voor het participeren aan deze ontwikkelingen, voor hun „éducation permanente”.

\section{Uitgangspunten.}

Voor de opzet, het programma en methoden van de opleiding gelden de volgende uitgangspunten:

- De opleiding gaat vooral uit van de eisen die de beroepsuitoefening stelt; deze hebben betrekking op het zelfstandig of ook in meer disciplinaire teams kun nen stellen van een verantwoorde diagnose in verschillende adviessituaties in hun maatschappelijke context en het kunnen kiezen en realiseren van daarop afgestemde adviesstrategieën.

- In de opleiding wordt gewerkt aan:

- verdieping van inzicht in organisatie-adviesprocessen en het functioneren van organisaties;

- vergroting van vaardigheden, welke in organisatie-adviesprocessen van belang zijn;

- ontwikkeling van eigen visie en houding met betrekking tot de uitoefening van het beroep.

- Voor de beroepsuitoefening is het van belang dat de adviseur zijn eigen mo. gelijkheden, beperkingen en aspiraties kent en zich kan verantwoorden over eigen benadering van probleemsituaties. De opleiding is erop gericht het ver. mogen tot reflectie op het eigen handelen verder te ontwikkelen.

- Het leerproces dient zodanig in verband te staan met de eigen werksituatie dat de praktijkproblematiek van de deelnemers in de leersituatie wordt gebracht en dat de verwerking van de leerstof zoveel mogelijk in de praktijk plaatsvindt.

- Huidige en toekomstige vragen uit de beroepsuitoefening bepalen welke de. len uit de organisatiekundige theorieën aan de orde worden gesteld.

- Er wordt zoveel mogelijk gebruik gemaakt van het potentieel dat in een cur. susgroep aanwezig is voor het bepalen en ontwikkelen van praktisch relevante kennis en vaardigheden en het bewust worden van houdingen.

\section{Programma.}

De opleiding wordt gegeven in conferentie-oorden in bijeenkomsten van twee en vier aanééngesloten dagen met tussenperioden van drie tot vier weken. In die tus. senperioden vervult de cursist zijn normale functie in de eigen organisatie, terwijl tevens studie- en huiswerkopdrachten worden uitgewerkt. Deze opdrachten betekenen een extra belasting boven de normale werkzaamheden.

Het programma bestrijkt een periode van twee jaar, onderbroken door onge. veer acht weken in de zomer.

De opleiding heeft drie onderscheiden studieperioden die achtereenvolgens gericht zijn op: 
1 Beeldvorming van beroep, maatschappelijke ontwikkelingen en eigen functioneren.

2 De beroepspraktijk; dimensies en vraagstukken.

3 Verdiepend onderzoek."

Tot zover de brochure.

Waar, voor het deelnemen aan de nieuwe SIOO-cursus zoals beschreven, als eis vier jaar praktijkervaring gesteld wordt na het behalen van een doctoraal examen, waarvan minstens twee jaren organisatie-adviespraktijk, zullen in de toekomst de meeste personen na het behalen van het diploma van het SIOO, rechtstreeks gewoon lid van de OOA kunnen worden.

De eerste deelnemers aan de nieuwe SIOO-cursus, die in overleg met de OOA tot stand is gekomen, zullen pas in het najaar van 1980 afstuderen. Dan kan pas blijken in hoeverre de vernieuwing van het SIOO-programma tot bevredigende resultaten heeft geleid.

\section{Conclusies t.a.v. postacademiale opleidingen op het gebied van organisatie-advieskunde}

Omdat de SIOO en de IOA-cursus van Philips de enige opleidingen vormen, die zich op wetenschappelijk niveau doelbewust op organisatie-advieskunde richten, wordt in dit artikel geen aandacht besteed aan andere postacademiale opleidin. gen. Naast de kenniselementen speelt training voor de beroepspraktijk een zekere rol terwijl veel aandacht wordt geschonken aan vormingselementen. Organisatie. advieskunde heeft naast het wetenschappelijke nog steeds iets ambachtelijks. Bovendien speelt de maatschappelijke verantwoordelijkheid en persoonlijke instelling een grote rol bij het uitoefenen van het beroep. Gezien de complexiteit en de dynamiek bij het uitoefenen van het beroep is het niet verwonderlijk, dat er zo'n nauwe binding bestaat in de personele sfeer tussen SIOO en OOA. Bovendien is er sprake van een institutionele binding, net zoals voor de IOA van Philips voorzien is. Op verzoek van Philips, zal de OOA nl. een lid afvaardigen in het curatorium van de interne opleiding tot organisatie-adviseur.

\section{Samenvatting en nabeschouwing}

Vakbekwaamheid en opleiding van de organisatie adviseur vormt een netelig on. derwerp. Men kan zich afvragen wie bepaalt wat de breedte van het vak is, wat de diepte van het vak is en welke opleiding voldoende breed en diep is als basis voor het wetenschappelijk en maatschappelijk verantwoord handelen van een or ganisatie-adviseur.

De OOA streeft naar verhoging van de vakbekwaamheid, naar de bevordering van opleidingsmogelijkheden daartoe en naar een ruime bekendheid en erkenning van het vak in de samenleving als voorwaarden tot verdere professionali. sering. Een moeilijkheid schuilt in de omschrijving van wat het jonge vak organisatiekunde precies inhoudt. Zo kan men van mening verschillen omtrent de noodzaak van een formele „wetenschappelijke” opleiding in advieskunde voor or ganisatie-adviseurs. Het vak blijft naast een wetenschappelijke fundering ook een ambachtelijke inslag hebben, terwijl het nog enigszins persoons- en situatie-gebonden is. 
Dit alles maakt het een hachelijke zaak objectieve maatstaven te formuleren voor beoordeling van de vakbekwaamheid bijvoorbeeld in verband met de toelating tot de Orde. Met het oog hierop en mede ten behoeve van democratisering heeft men twee jaar geleden de procedure voor toetreding tot de Orde gewijzigd. Onder bepaalde voorwaarden kunnen thans drie leden als referent optreden van een aspirant-lid. De Commissie van Onderzoek voor de toelating van nieuwe leden toetst op haar beurt de drie adviezen, waarbij vooral op overeenkomst en verschil wordt gelet. Door deze procedure is een dynamisch leerproces op gang gekomen, waardoor zich wijzigende waarde-opvattingen binnen het ledenbestand tot uiting komen bij de toelating.

Bij de beoordeling van de vakbekwaamheden speelt naast ervaring, de formele opleiding een grote rol. Een onderscheid kan gemaakt worden tussen training, opleiding en vorming. Bij training is er sprake van het inoefenen van elementaire kennis en vaardigheden, zodat deze als het ware ,automatisch" ter beschikking staan. Bij opleiding vindt er integratie plaats tussen verschillende kennisgebieden, waardoor inzicht door kan breken. Bij vorming wordt de kennis in de persoon. lijkheid van de hele mens geïntegreerd. Dit betekent dat niet alleen het intellec. tuele weten en denken wordt ontwikkeld, niet alleen vaardigheden, maar dat ook aan de ontwikkeling van het gevoels - en wilsleven aandacht wordt besteed. In dit artikel wordt de nadruk gelegd op wetenschappelijke kennis en inzicht. Niet vergeten moet echter worden, dat elke opleiding ook trainings en vormingselemen. ten in zich draagt.

Achtereenvolgens worden de volgende drie typen universitaire opleidingen be handeld:

- de mono-disciplinaire opleidingen, te weten de technische, de economische, de psychologische en de sociologische,

- de bedrijfskundige opleidingen te Eindhoven, Twente en Delft/Rotterdam (Groningen als nieuwe opleiding wordt als zodanig slechts genoemd), en

- de post academische opleidingen, te weten de SIOO en de IOA van Philips. De bedrijfskundige en de post-academische opleidingen worden door de OOA aanvaard als voldoende basis voor het kennis niveau. De eerstgenoemde opleidin. gen worden niet zonder meer aanvaard, omdat die voorlopig als te specialistisch beschouwd worden.

Deze mono-disciplinaire opleidingen beperken zich - misschien met uitzondering van de technische - tot kennis en inzicht. In de bedrijfskundige opleidingen wordt ook aandacht gegeven aan training van vaardigheden, terwijl bij de postacademische opleidingen ook vormingselementen een grote rol spelen.

In dit artikel komt naar voren, dat er een groot aanbod en verscheidenheid aan opleidingen bestaat, waarbij organisatie kunde in een of andere vorm van belang is. Dit maakt, dat het voor een organisatie-adviseur moeilijk is vooraan te blijven in zijn vak. Binnen cliënten-organisaties is er een groeiend niveau van kennis aanwezig. Dit betekent dat de aard van het adviseren zal veranderen. Aan de vak. bekwaamheid van de (externe) organisatie-adviseur zullen steeds hogere eisen gesteld worden. Veel van het organisatiewerk zal - nog meer dan nu het geval is - gaan bestaan uit het samenwerken met specialisten en niet-specialisten van de betreffende organisatie.

Het grotere aanbod van afgestudeerden en de grote verscheidenheid aan opleidingen op het gebied van organisatie-kunde, zal ook van invloed zijn op de ver- 
deling van leden en activiteiten over een aantal beroepsverenigingen zoals de OOA, KIVI, NIVRA, NPV, etc. Het aantal van 600 leden maakte een zekere dif. ferentiatie binnen de OOA thans reeds mogelijk. Het komt mij wenselijk voor dat deze differentiatie op natuurlijke wijze naar behoefte moet groeien vanuit werk. groepen e.d., en niet te snel geïnstitutionaliseerd moet worden. Vele differentia. ties zijn mogelijk en het staat geenszins vast dat verbijzondering op basis van de klassieke disciplines voorkeur verdient!

\section{Aangehaalde literatuur}

1. Braun, C. A., red., Universitaire bedrijfskundige opleidingen, Stichuing Bedrijfskunde, Rotterdam (thans Delft), 1971

2. Wattel, A., red., Review of Management education in the Netherlands, Interfaculteit Bedrijfskunde, Gro ningen, mei 1976

3. Vis, J., Werken met adviseurs, Lezingencyclus 2425 juni 1977, Bijzondere Cursussen onder redactie van Ir. J. W. Geevers, Zwijndrecht, 1977.

4. Blake, R. R. en Mouton, J. S., Consultation, Addison.Wesley, Reading, 1976.

5. Ruijter, H. de, J. H. D. Wiersema, Typering van adviesprocessen, in: Organisaties in Ontwikkeling, J. J. J. van Dijck en J. A. P. van Hoof, 1976.

6. Vliert, E v. d., De organisatie adviseur: controleur? loods? coach?, Intermediair, 6e jrg., 19, 15 mei 1970

7. Lippitt, R. en Lippitt, G., Consulting process in action, I and II, Training and Development Journal, May. June 1975.

8. Reddin, W. J., Effective MBO, Management Publ., Ltd., B.I.M., London, 1971

9. Management methoden en technieken, Kluwer, Deventer, vanaf 1976.

10. Bergen, J. E. J. van, enz. red. Organisatie adviseurs . . ook maar mensen, Stenfert Kroese, Leiden, 1977.

11. Bos, A. H., Leren, Encyclopedie van de Bedrijfseconomie, deel III, Organisatie, pag. 179, Kluwer, Deventer.

12. Leavitt, H. J. (1965), Applied organizational change in industry in March. J. G. (ed.), Handbook of organizations, Rand McNally.

13. Handy, Charles B., Understanding organizations, p. 363, Penguin education, 1976.

14. In 't Veld, J., De opleiding industriële organisatie, uitgave 9, TH Delft.

15. Eyzenga, G. R. (red.), Planning en beheersing van organisaties, Elsevier, Amsterdam/Brussel, 1977.

16. Dongen, H. J. van, Naar een perspectief, opgenomen als hoofdstuk IV in Ramondt, J. J. (red.), Personeel beleid in opspraak door inspraak, Samsom, Alphen, 1976. 